\title{
Investigating the Effect of Self-regulatory Strategy Development on Iranian EFL Learners' Metadiscoursal Writing Skill
}

Mehrnoosh Eslami ( $\square$ eslamimehrnoosh@gmail.com )

Shiraz University https://orcid.org/0000-0001-5609-0445

Rahman Sahrahgard

Shiraz University

Original article

Keywords: Iranian EFL Learners, Metadiscoursal Writing Skill, Self-regulatory Strategy

Posted Date: July 30th, 2020

DOI: https://doi.org/10.21203/rs.3.rs-44891/v1

License: () (1) This work is licensed under a Creative Commons Attribution 4.0 International License. Read Full License

Version of Record: A version of this preprint was published at Language Teaching Research Quarterly on March 1st, 2021. See the published version at https://doi.org/10.32038/Itrq.2021.21.04. 


\section{Abstract}

The current research was an attempt to investigate the effect of self-regulatory strategy instruction on Iranian EFL learners' metadiscoursal writing skill. To this end, 50 Iranian EFL intermediate learners, studying English language in an institute were selected through convenience random sampling. All of them were Persian native speakers. Three research instruments were utilized to gather the data, namely, Selfregulated Strategies Intervention, and Metadiscoursal writing pretest and posttest. Due to the situation of Covid-19, the instructor made a WhatsApp group, besides the virtual group using Adobe Connect to be in contact with the learners. The learners took a metadiscoursal writing pretest. For the next six sessions, the participants were taught intervention, via self-regulated strategies and they were supposed to follow the instructions. The instructor checked every learner's progress. Finally, they took a posttest, and the results obtained from the research instruments were analyzed through paired samples t-test. The findings revealed that self-regulatory strategy instruction had a positively significant effect on Iranian EFL learners' metadiscoursal writing skill and it is suggested that teachers are better to get familiar with the self-regulated strategy and its positive outcomes.

\section{Introduction}

Self-regulation, a psychological concept which has attracted the attention of many educational researchers (Zimmerman, 1990), is defined as self-generated thoughts, feelings, and behavior that are planned and cyclically adapted based on performance feedback to achieve selfset goals (Zimmerman, 1989). Zimmerman (2008) viewed self-regulated learning (SRL) as including such processes as setting goals, planning strategically, selecting and using strategies, self-monitoring one's effectiveness and self-evaluation while learning and remembering knowledge and academic skills. Similarly, Schunk and Zimmerman (1997) defined SRL as an approach to making learners autonomous in such a way that they are motivationally, behaviorally and metacognitively active and able to take responsibility for their own learning and problem-solving. This process of making learners autonomous implies that self-regulation is an ability that can be developed. Evidence of the self-regulation teachability can be found in Palincsar and Brown (1984), who showed that self-regulatory processes and strategies can be instructed, and teachers can train learners in self-regulation. This has been confirmed by subsequent research as well (e.g. Perels, Gurtler, \& Schmitz, 2005; Perry, Hutchinson, \& Thauberger 2007; Stoeger \& Ziegler, 2008).

On the theoretical side, there are those who argue that self-regulation plays a major role in reading comprehension. For instance, according to Davis and Gray (2007), readers must use self-regulated strategies to completely use their abilities to understand texts. In other words, SRL leads to engaged reading comprehension when self-regulated readers monitor and adjust their performance in order to meet their individual learning needs. It has also been proved empirically that self-regulatory reading strategies enhance - the student's own planning, decisionmaking, reflection and evaluation of effective reading strategies" (Mulcahy-Ernt \& Caverly, 2009, p. 191), and that self-regulatory processes including selecting and using strategies (Zimmerman, 2008) have proved to be major factors in enhancing reading ability (Kumi-Yeboah, 2012).

Writing is a medium of human communication that represents language with signs and symbols. Writing is not a language, but a tool used to make languages readable. The outcome of writing is called text and the addressee of text is called a reader. In recent years, a great attention is given to writing. Writing is a skill, which is often neglected until more advanced stages of language learning. However, it is definitely necessary for those learners who intend to continue their studies in English and majors other than English. It may also be necessary for other purposes such as submitting papers for publication and conferences (Marandi, 2003).

Today, the use of metadiscourse markers in different texts has attracted many researchers. Metadiscourse is an area which deals with the ways which the writers and speakers use language to interact with readers or listeners and it is a widely used term within discourse analysis as well as language teaching. There are many definitions about metadiscourse for example, Hyland (2005) says "Metadiscourse is a key resource in language, as it allows the writer to engage with readers in familiar and expected ways. Writers use the devices of metadiscourse to adjust the level of personality in their texts, to offer a representation of themselves and their arguments. This helps the reader to organize, interpret and evaluate the information presented in the text. Metadiscourse is therefore crucial to successful communication" (p. 22). So, we can say that metadiscourse is a link between text and its context of use according to different expectations that readers have (Hyland,

2005). Crismore (1983) also defined metadiscourse as "Writing about writing, whatever does not refer to the subject matter being addressed" (p. 15). It is also used in writing to describe a word or phrase that comments on what is in the sentence, usually as an introductory adverbial clause or simply it is an author's discoursing about the discourse; it is the author's intrusion into the discourse, either explicitly or nonexplicitly, to direct the reader rather than inform (Crismore, 1983).

\section{Statement Of The Problem}


Self-regulated learners are students who are actively participate in their own learning, rather than rely solely on teachers, parents, or other external change agent to impart knowledge (Alexander, 1997). Teachers describe students who exhibit self-regulated behavior as selfstarters who persist on instructional task, prevail over problems, and react appropriately to task performance outcomes (Zimmerman, 1997). In contrast, students who lack self-regulation are more likely to exhibit impulsive behavior, set lower academic goals, inaccurately assess their abilities, engage in self-criticism, experience limited academic success, and give up easily.

Research on academic self-regulation learning began as an outgrowth of psychological investigation into self-control among adults and its development in children (Zimmerman, 2001). Much early self-regulation research was therapeutic in nature; researchers taught participants to alter dysfunctional behavior such as aggression, addiction, and behavioral problems. Researchers now apply self-regulatory principles to academic studying and other forms of learning such as social and motor skills (Schunk, 2005). The context of Educational Psychology has seen profound changes over the last 30 years, due to these self-regulated learning has become a current focus for research, and one of the essential axes of educational practice (Pintrich, 2000a; Reynolds \& Mirler, 2003).

In terms of academic achievement, self-regulation is the fusion of skill and will. Students with effective self-regulation have learned to plan, control, and evaluate their cognitive, motivation, affective, behavioral, and contextual processes. They understand how to learn, selfmotivate, and recognize their possibilities and limitations. As a function of this knowledge, they can control and regulate their learning processes in order to adjust to task objectives and context, to optimize their performance and improve skills through practice (Artino, 2008; Miller \& Bricman, 2004; Montalvo \& Torres, 2004; Paris; 2004). Murcia (2001) claims that within the communicative framework of language teaching the skill of writing enjoys special status. It is via writing that a person can communicate a variety of massages to close or distance known or unknown reader or readers. Such communication is extremely important in the modern world, whether the interaction takes the form of traditional paper and pencil writing or the most technologically advanced electronic mail. Writing as a communicative activity needs to be encouraged and nurtured during the language learning course of study. Viewing writing as an act of communication suggests an interactive process which takes place between the writer and the reader via the text. Such an approach place value on the goal of writing as well as on the perceived reader audience.

Chastein (1976) defines writing as a basic communication skill and unique asset in the process of learning a second language. Both aspects of writing are important in the typical language class and both can serve to reinforce the other. He or she adds writing goals like those in the other three language skills vary with the teacher. Some teacher focuses almost entirely on the language itself, some on communication, and other on both the forms and massage.

In fact, writing good essays are to be signs for EFL learner's language command. However, students are found to have some difficulties in writing good essays. In the process of pursuing learners' development it is observed that students have problems with writing narrative essays and stories. This can be attributed to different learning factors or teaching environments. To overcome these difficulties it is essential to search for other tools that can enhance students' narrative writing. This obligates to reconsider the methods of teaching and the curriculum of teaching students' meta discourse writing.

Metadiscourse is an area, which has got attention in the last few decades. Having the ability to recognize metadiscourse markers in a text will help readers to have a better understanding of the text and make the text easier to read. There are hundreds of standard articles that have been written in this area and across different registers. Metadiscourse markers are closely related to registers. They can guide readers through the text easily. There are also lots of articles that have focused on the use of metadiscourse markers in specific registers and sub registers, but a few study on register variation of metadiscourse markers in general (Zhang, 2017) has done multidimensional analyses of written and spoken registers.

Therefore, finding the appropriate methods to teach metadiscourse writing in EFL context is of paramount importance. One of these methods is developing the self-regulatory strategy among the learners. To this end, the current study was an attempt to investigate the effect of self-regulatory strategy instruction on Iranian EFL learners' metadiscourse writing skill.

\section{Significance of the Study}

In domain of language teaching the importance of understanding dynamic interaction between personal and contextual factors which are involved in the process of learning English as a foreign language is undeniable (Albert, 2006; Dorneyei \& Skehan, 2003). Therefore, SR plays an important role in psychological trends. Moreover, it is largely believed that learners' psychological factors play an important role in the process of learning a language (Lightbown \& Spada, 2013). It is also assumed that establishing a self-regulated learning environment in the classroom may optimize language learning and teaching. 
The growing need for promoting Self-Regulation though has led to what some educators such as Dam (1995), and Ku (2009) attached great importance to the necessity of SR in learning. According to their findings, self-regulated students are more able to succeed academically and motivated. Thereof being aware of the ways to increase understanding of this notion and the ways to improve it will accelerate leaning process. Based on previous researches in this field, awareness of learning styles of every individual is a useful solution to ease learning and achieve the ultimate goal of language learning which is being able to communicate, so it is highly recommended that every learner learns about his learning styles before starting learning process.

The findings of the current study might be fruitful for EFL teachers, learners, as well as curriculum and syllabus designers. In addition, policy makers in the realm of the ELT may benefit from the results of the present research.

\section{Review of Literature}

For long, the researchers have studied the self-regulation and language skills (e.g. Tseng, Dörnyei \& Schmitt, 2006). In a study by Sentürk (2016), she found that the relationship between Turkish EFL learners' self-regulated learning components and vocabulary knowledge in terms of their proficiency level and vocabulary depth and breath. The findings showed that the presence of a strong positive relationship between self-regulation, vocabulary depth and breath.

In addition, Zarei and Hatami (2012) did a study to explore the relationship between Iranian EFL college students' self-regulated learning and their vocabulary knowledge and reading skill. Conducting the intended tests and questionnaire, they found different findings in the relationship among the various self-regulated learning elements. Moreover, it was concluded that no significant relationship was found between self-regulated components and the vocabulary knowledge.

Hardi (2014) sought to examine Hungarian primary school learners' vocabulary learning strategies in the framework of self-regulation. He used interviews and questionnaires, as well as classroom observations. Actually, the researcher wanted to tap into the learners' own perceptions of their learning processes. The results of the study indicated that young learners utilized various vocabulary leaning strategies.

In another study, Nabavi Ekhlas and Shangarffam (2012) investigated the relationship between the sub-factors of self-regulated strategies and four language skills and overall proficiency among Iranian IELTS candidates. The results indicated that behavioral self-regulated strategies positively had a direct relationship with the language skills.

Reviewing the literature also shows that a number of research have demonstrated across gender differences in use of self-regulated learning strategies in their learning. For instance, Lee (2002) proposed that three main gender difference issues in self-regulated learning strategies from literature. Likewise, in another study, Young and McSporran (2001) found other gender differences regarding the self-regulation, motivation, strategies learning, and skill learning.

Recently, Fatemipour and Najafgholikhan (2015) investigated the effect of self-regulated strategy on vocabulary learning of Iranian EFL students as well as the role of gender. 60 Iranian intermediate EFL learners participated in the study. The experimental was taught additional training in use of self-regulated strategy on vocabulary. The results showed that self-regulated strategies had significant positive effect on the learners' vocabulary learning, while no difference was found among genders.

\section{Method}

\section{Participants}

The participants of this study included 50 Iranian EFL intermediate learners who are studying English language in an institute in Shiraz, Iran. Due to the recent COVID-19 restrictions, all the classes were held through virtual courses. They ranged from 19 to 26 years old with a mean age of 22.5. The researcher selected the learners through convenience random sampling from among intermediate learners in which all were Persian native speakers.

\section{Research Instruments}

Three instruments were utilized in the present study:

\section{Self-regulated Strategies Intervention}


The self-regulation strategies intervention were selected from Graham and Harris's, (2005b). They developed six stages for self-regulation development called SRSD, which allowed students to learn and apply a reading strategy (Graham \& Harris, 2005b). However, these stages were intended to be used as a beginning framework for instruction and can be reordered, combined, modified, and repeated, based on students' needs.

\section{Metadiscourse Writing Pretest \& Posttest}

Two tests as pretest and posttest, which were constructed by the researcher to measure metacognitive writing knowledge of the participants included three topics from among which students could choose their favorite one and write a piece of metadiscourse writing in 40 minutes. In order to score the participants' writings during this stage, ACT Aspire assessment rubric for writing was used. Besides, they were rated by two raters.

\section{Procedure}

For the purpose of the current study, a pretest posttests research design was used. To this end, first, 50 Iranian EFL male and female learners of an institute in Iran at virtual courses were selected. They were then divided into one experimental and one control group. To this end, the instructor taught both groups through online teaching. She also made a Whats App group to be in contact with the learners in each group. The learners were supposed to follow the instructions. Then, they took a metadiscourse writing pretest. Then, the participants were taught via self-regulated strategies intervention for six sessions. The instructor checked every learner's progress. Finally, they took a posttest, and the results obtained from the research instruments were analyzed through paired samples t-test.

\section{Results}

Before comparing the performance of the two groups, it is essential to check the hypothesis of the parametric test before selecting the appropriate statistical test. According to Field (2013), hypotheses using parametric statistical tests include the normality of the distribution, the uniformity of the variance, and at least the independence of the interval variable and the measurement. The kurtosis and skewness values of each group and their corresponding z-scores are calculated to test the first hypothesis.

Table 1. Skewness and kurtosis values

\begin{tabular}{|lllll|}
\hline & Skewness & Std. Error of Skewness & Kurtosis & Std. Error of Kurtosis \\
\hline Experimental & -.112 & .328 & -.624 & .749 \\
Control & .165 & .314 & -.759 & .616 \\
\hline
\end{tabular}

Regarding experimental group, the z-score of skewness was 0.352, and the kurtosis z-score was 0.909. The control group's z-score of skewness was 0.469 , and their kurtosis z-score was 1.009 . Comparing the z-scores against the known values for the normal distribution indicates that value greater than 1.86 is significant at $p<.05$. As it is evident, none of the z-scores is higher than 1.86 , which indicates a normal distribution of the scores. Furthermore, to examine the second assumption, namely, the homogeneity of variances, Levene's test was run. Table 2 presents the results.

Table 2. Levene's test results

\begin{tabular}{|lllll|}
\hline & Levene..Statistic & $\mathrm{df1}$ & $\mathrm{df2}$ & Sig. \\
\hline Based on Mean & .084 & 1 & 48 & .722 \\
\hline Based on Median & .078 & 1 & 48 & .719 \\
\hline Based on Median and with adjusted df & .078 & 1 & 46.02 & .719 \\
\hline Based on trimmed mean & .082 & 1 & 48 & .720 \\
\hline
\end{tabular}


According to Table 2, the Levene's test is non-significant at $p \leq .05$. Thus, it is concluded that the difference between the groups' variances is not significant and roughly equal, and therefore the assumption of homogeneity of variances is met. Since the main assumptions of the parametric test were met, the independent sample t-test could be run. The descriptive statistics of two groups were calculated and presented.

Table 3. The descriptive analysis of the experimental and control groups

\begin{tabular}{|cccccc|}
\hline & N & Min. & Max. & M & SD \\
EG & 25 & 68 & 78 & 73 & 2.56 \\
CG & 25 & 65 & 73 & 69 & 2.28 \\
\hline
\end{tabular}

Table 4 illustrates the results of independent samples t-test for two groups.

\section{Table 4. Independent samples t-test for two groups}

\begin{tabular}{|c|c|c|c|c|c|c|c|c|c|}
\hline \multicolumn{3}{|c|}{$\begin{array}{l}\text { Levene's Test for } \\
\text { Equality of Variances }\end{array}$} & \multicolumn{7}{|c|}{ t-test for Equality of Means } \\
\hline \multirow[t]{2}{*}{$\mathrm{F}$} & \multirow[t]{2}{*}{ Sig. } & & \multirow[t]{2}{*}{ df } & \multicolumn{2}{|c|}{ Sig. (2-tailed) } & \multirow[t]{2}{*}{$\begin{array}{l}\text { Mean } \\
\text { Difference }\end{array}$} & \multirow[t]{2}{*}{$\begin{array}{l}\text { Std. Error } \\
\text { Difference }\end{array}$} & \multicolumn{2}{|c|}{$\begin{array}{l}95 \% \text { Confidence } \\
\text { Interval of Difference }\end{array}$} \\
\hline & & & & & & & & Lower & Upper \\
\hline $\begin{array}{l}\text { Equal } \\
\text { variances } \\
\text { assumed }\end{array}$ & .772 & .382 & .077 & 48 & .939 & .067 & .866 & -1.649 & 1.782 \\
\hline $\begin{array}{l}\text { Equal } \\
\text { variances } \\
\text { not } \\
\text { assumed }\end{array}$ & & & .077 & 46.905 & .939 & .067 & .866 & -1.649 & 1.782 \\
\hline
\end{tabular}

As shown in Table 4, since Levene's Test result is significant, that is, we observed $p<0.05$, then we would use the "Equal variances assumed" output. In t-test for Equality of Means, since $p<.939$ is less than our chosen significance level $a=0.05$, and therefore it is concluded that there is a significant difference between two groups' performance. That is, the experimental group outperformed their counterparts in the control group verifying the effect of self-regulatory strategy instruction on Iranian EFL learners' metadiscourse writing skill.

Todays, a number of EFL/ESL teachers might pave the way for the learners to practice both language skills and self-regulating behaviors. In addition, the learners may get feedback during language learning process, so it might encourage them to become independent on driving their own learning. Another effective element in enhancing the learners' self-regulated learning is the learning environment. According to Zimmerman (2002), the role of environment in learners' self-regulated learning proves that environmental factor affects bidirectional interaction with learners' personal and behavioral features. The interaction with environment results in the cyclical development and adaptation of learners' self-regulation. Therefore, the environment can be effectively utilized to enhance students' self-regulation.

The current findings of this study are in line with a number studies such as Hardi (2014), Zarei and Hatami (2012), and Sentürk (2016), which revealed that self-regulated strategies had a significant effect on vocabulary learning. Therefore, in a classroom where self-regulated strategy instruction is utilized, learners can be provided with the opportunity for using the practical strategies, which be fruitful in their academic outcome, accordingly.

\section{Conclusions}

As a result of the findings of literature and the present study, it is suggested that teachers are better to get familiar with the self-regulated strategy and its positive outcomes. Although it has not currently applied in EFL classrooms, it is still needed to be more investigated and clarified in different contexts. In-service training sessions can be a good place for both Experienced and newly hired teachers to get to know this term and how to apply them especially to improve the Meta cognitive writing skills of their learners. Additionally, institutions of English Language and other EFL centers can integrate this strategy into their curriculum and make a chance for development of metacognitive 
writing of students. This strategy can also be applied at universities particularly for the ones who want to teach in future. Lastly, it is recommended that further research can be done to study self-regulated strategy development in teaching other language.

\section{List Of Abbreviations}

- SRL (self-regulated learning)

- EFL (English as a Foreign Language)

- ELT (English Language Teaching)

\section{Declarations}

\section{Availability of data and material}

Not applicable

\section{Funding}

Not applicable

\section{Competing interests}

The authors declare that they have no competing interests."

\section{Authors' contributions}

E and R. S gave the idea of the paper. M.E collected the data and wrote the first draft of the paper. Together, they did the data analysis. R.S revised the paper in different stages of the study. The authors read and approved the final manuscript.

\section{Acknowledgements}

Not applicable

\section{References}

1. Abednia, A., Hovassapian, A., Teimournezhad, S., \& Ghanbari, N. (2013). Reflective journal writing: Exploring in-service EFL teachers' perceptions. System, 41(3), 503-514.

2. Akbari, R. (2007). Reflections on reflection: A critical appraisal of reflective practices in L2 teacher education. System, 35(2), $192-207$.

3. Andrusyszyn, M. A., \& Davie, L. (1997). Facilitating reflection through interactive journal writing in an online graduate course: A qualitative study. Journal of Distance Education, 12(1), 103-126.

4. Aneiro, S. (1989). The influence of receiver apprehension in foreign language learners on listening comprehension among Puerto Rican college students. Unpublished doctoral dissertation. New York, NY: New York University.

5. Barkhuizen, G. (2011). Narrative knowledging in TESOL. TESOL Quarterly, 45(3), 391-414.

6. Dewey, J. (1933). How we think: A restatement of the relation of reflective thinking to the educative process. Boston, MA: Houghton Mifflin.

7. Griffith, B., \& Frieden, G. (2000). Facilitating reflective thinking. Counselor Education \& Supervision, 40(2), 82-92.

8. Hawkins, M., \& Norton, B. (2009). Critical language teacher education. In A. Burns \& J. Richards (Eds.), Cambridge guide to second language teacher education (pp. 30-39). Cambridge, MA: Cambridge University Press.

9. Karimvand, P., Hessamy, G., \& Hemmati, F. (2014). The place of postmethod pedagogy in teacher education programs in EFL language centers of Iran. Iranian Journal of Applied Linguistics (IJAL), 17(2), 59-91.

10. King, P., \& Kitchener, K. (1994). Developing reflective judgment: Understanding and promoting intellectual growth and critical thinking in adolescents and adults. San Francisco, CA: Jossey-Bass. 
11. Kumaravadivelu, B. (2003). Beyond methods: Macrostrategies for language teaching. London: Yale University Press.

12. Kumaravadivelu, B. (2006). Understanding language teaching: From method to postmethod. Mahwah, NJ: Lawrence Erlbaum.

13. Shokouhi, H., Daram, M., \& Sabah, S. (2011). Shifting between third and first person points of view in EFL narratives. Arts and Humanities in Higher Education: An International Journal of Theory, Research and Practice, 10(4), 433-448.

14. Tang, R. (2009). Developing a critical ethos in higher education: What undergraduate students gain from a reader response task? Reflections on English Language Teaching, 8(1), 1-20.

15. Weisberg, H. F., Krosnick, J. A., \& Bowen, B. D. (1996). An introduction to survey research, polling, and data analysis (3rd ed.). Newbury Park, CA: Sage.

16. Young, S., \& McSporran, M. (2001). Confident men - successful women: Gender differences in online Learning. In C. Montgomerie \& J. Viteli (Eds.), Proceedings of EdMedia 2001 Conference (pp. 2110-2112), Chesapeake, VA: AACE.

17. Yu-Ling, L. (2005). Teaching vocabulary learning strategies awareness, beliefs, and practices. A survey of Taiwanese EFL Senior high school teachers. Unpublished master's thesis, University of Essex.

18. Zarei, A. A., \& Hatami, G. (2012). On the relationship between self-regulated learning components and L2 vocabulary knowledge and reading comprehension. Theory and Practice in Language Studies, 2(9), 1939-1944.

19. Zimmerman, B. J. (2002). Becoming a self-regulated learner: An overview. Theory Into Practice, 41 (2), 64-70lip> 